\title{
Munkajogi és gazdasági kihívások a jövő munkaerőpiacán
}

\section{The Challenges of the Labour Law and Economic in the Future Labour Market}

\author{
G. MÉLYPATAKI ${ }^{1}$, K. LIPTÁK ${ }^{2}$ \\ ${ }^{1}$ Miskolci Egyetem, Állam- és Jogtudományi Kar, Agrár- és Munkajogi Tanszék, jogmega@uni-miskolc.hu \\ 2Miskolci Egyetem, Gazdaságtudományi Kar, Foglalkoztatáspolitika és Munkaerőpiac Tanszék, regkata@uni- \\ miskolc.hu
}

\begin{abstract}
A kutatást az EFOP-3.6.2-16-2017-00007 azonosító számú, Az intelligens, fenntartható és inkluzív társadalom fejlesztésének aspektusai: társadalmi, technológiai, innovációs hálózatok a foglalkoztatásban és a digitális gazdaságban címú projekt támogatta. A projekt az Európai Unió támogatásával, az Európai Szociális Alap és Magyarország költségvetése társfinanszírozásában valósul meg.
\end{abstract}

\begin{abstract}
Absztrakt. A tanulmány célja megvizsgálni azt, hogy a globalizáció hatásai milyen módon érintik a globális munkaerőpiacot, hogyan befolyásolja a nagyfokú automatizáció és digitalizáció a munkaeröpiac szereplöivel szembeni elvárásokat, a munkajog világát. Elemezzük az ipar új kihívásaival kapcsolatos kompetenciák megszerzésének jogi kereteit és közgazdasági, társadalmi hasznosságát. Részletesebben vizsgáljuk az alacsony képzettségű munkaerő jövőjét a változó munkaerôpiacon, az új kompetenciák megszerzésének a függvényében. Feltevésünk szerint a munkaerốpiacon végbemenő változások és újszerü folyamatok új kihívásokat támasztanak a munkaadók és a munkavállalók számára is. A munkaerő-piaci változások felvetik azokat a kérdéseket, hogy az állását elvesztô munkavállaló az új kompetenciák megszerzéséig milyen ellátásban részesüljön. A mai értelemben vett szociális ellátó rendszer képes-e támogatni az élethosszig tartó tanulást, vagy szükséges-e olyan alternatív megoldási lehetőségek vizsgálata, mint az alapjövedelem? Mindezeknek a jogi és közgazdasági vizsgálata, a hatékonyság és gazdaságosság fogalmainak tükrében szükséges megvalósítani. Ennek oka, hogy az új munkavállaló kompetenciák megszerzése, új hozzáadott értéket is jelent.
\end{abstract}

Abstract. The aim of the study is to examine how the effects of globalization affect the global labor market, and how high-level automation and digitalization affect the expectations of labor market actors and the world of labor law. We analyze the legal framework and the economic and social utility of acquiring competences for new challenges in the industry. We will look in more detail at the future of the low-skilled labor force in a changing labor market as a function of acquiring new competencies. We believe that changes in the labor market and novel processes will also pose new challenges for employers and employees. Changes in the labor market raise the question of what kind of benefits an outgoing worker will receive until he or she acquires new competencies. Is the social welfare system in the current sense capable of supporting lifelong learning, or is it necessary to explore alternatives such as basic 
income? All this needs to be done in the light of the legal and economic scrutiny of the concepts of efficiency and economy. This is because acquiring competences for the new employee also brings new added value.

\section{Bevezetés}

A szakirodalomban nagy vitát okoz a globalizáció jelenség felismerésének pontos datálása. Egyes kutatók szerint a globalizáció a 20. században jelent meg. [1] Az Európai Tanács torinói csúcsértekezletén (1996. március) a gazdasági globalizáció jelenségében látták az egyik legnagyobb kihívást, amellyel az Európai Uniónak szembe kell néznie a 20. század végén, illetve a 21. század elején. Az ott megfogalmazottak szerint a globalizáció semleges fogalom, amely bizonyos keretfeltételeket és fejlődési impulzusokat teremt, bár kétségtelen, hogy az információk, az áruk és a tőkék mozgása előtti korlátok lebontása nyomán erősödik a verseny, gyengül a nemzeti monetáris és gazdaságpolitikák cselekvési autonómiája. Ezzel együtt jórészt a gazdasági szereplőkön múlik, hogy melyek és milyenek a globalizálódás következményei. A globalizáció munkaerőpiacot érintő hatásaként a szakirodalomban egyre gyakrabban találkozunk a 20-80 társadalom fogalmával. [2] [3] [4] Eszerint a nézet szerint a jövőben várhatóan elég lesz $20 \%$ foglalkoztatott a teljes népességen belül, hogy a világgazdaságot lendületben tartsák.

A globalizáció munkaerő-piaci hatásai összetettek, a munkaerőpiacok egyre növekvő felbolydulása nemcsak a bizonytalanságot és egyenlőtlenséget növeli a képzettségi kategóriákon belül, hanem a képzetlen munkások relatív munkabéreinek egészére is csökkenő hatással van. A globalizáció fő hatása a munkaerőpiacokra leginkább a munkaerő iránti kereslet rugalmasságának növekedésében és nem pedig a kereslet általános csökkenésében nyilvánul meg. [5]

\section{A globalizáció munkaerő-piaci hatásai}

\subsection{Technológiai változás}

Az információs forradalom, a digitalizáció és az automatizáció a cégeknek felkínálja a lehetőséget arra, hogy javuljon belső hatékonyságuk, növekedjen a termelékenységük és a földrajzi távolság áthidalható legyen a szereplők között. Technológiához való hozzáférés hiánya az alacsony jövedelemmel rendelkezők helyzetét nehezíti és növeli a szegénység szintjét. Kétségkívül a technológiák változása létfontosságú tényezője a növekedésnek és a fejlődő világ előretörésének. A technológiai változások fokozatosan kiváltják a munkaerő egy részét és ezzel párhuzamosan egy minőségi átértékelődés is elkezdődött a munkaerőt illetően.

\subsection{Szektorális változások}

Az elmúlt két évtizedben strukturális átalakulás volt megfigyelhető: a feldolgozóipari termelés és létszám csökkent, ugyanakkor a szolgáltatások, pénzügyi tevékenység, építőipari termelés és létszám növekedett. Ezt az időszakot a gyors gazdasági növekedés és állásteremtés időszakaként jellemezhetjük. Viszont ez a fellendülés sokkal inkább kedvezett a magas, mint a közepes és alacsony 
jövedelmű csoportoknak. A globalizáció hatásának is betudhatjuk a foglalkoztatottak átrendeződését a szolgáltató (tercier), az ITC (kvaterner) szektorokba. A szektorális átrendeződések eredményeképpen azt várták, hogy a szolgáltató szektor meg tudja oldani a munkanélküliség kérdését és munkalehetőséget biztosít, de ez nem valósult meg teljes mértékig. A szektorális változások eredményeképpen megváltozott a munkaerő mennyisége és minősége iránti igény is.

\subsection{A munkaerő mobilitásának növekedése}

A termelés-kihelyezést tekinthetjük a munkaerő keresletet befolyásoló tényezőjeként, amely a migráció kínálati oldali változását befolyásolja. Nagy (2010) szerint a globális gazdaságban a termelési tényezők a korábbihoz képest magasabb mobilitással járnak, így a munkaerő, mint gazdasági tényező globalizációja alatt az államhatárokat átlépő mozgásokat érti. A globális munkaerőpiac új szerveződési rendet követ, az egyes szektorok eltérő súlya eredményezi az egyre megosztottabb munkaerőpiacot, aminek eredményeképpen egy a korábbinál rugalmasabb, ugyanakkor bizonytalanabb munkaerőpiac alakul ki. [6] A kedvezőtlen folyamatokhoz társul a munkaképes korú lakosság globális csökkenése, a világ országaiban 2 százalékpontos csökkenés tapasztalható 30 év leforgása alatt. A különböző tényezők a migrációs tendenciák tekintetében sem választhatók el könnyen egymástól. Kelet-Európa növekvő számban fogad főleg kvalifikált külföldieket, de a küldő jelleg érvényesül erőteljesen. [7] Tény, hogy a fejlődő és az átalakuló országokban is nő a bérkülönbség a képzett és a képzetlen dolgozók között. A külföldi befektetésekkel ez annyiban függ össze, hogy átlagban magasabban képzett munkaerőt foglalkoztatnak. A fizikai dolgozóknak a külföldi cégek sem fizetnek többet, mint a hasonló termelékenységű hazaiak. [8] A migráció napjainkra világjelenséggé vált, az alacsony képzettségü, alacsony bérű munkaerő beáramlása a kínálat bővülése által kis mértékben növeli a munkanélküliséget.

\subsection{A foglalkoztatottság csökkenése és a munkanélküliség növekedése}

A globalizáció hatásaként a technológia fejlődése egyre inkább kiszorítja az élőmunkát a termelésből, ugyanakkor a tőkének szüksége van a munkaerőpiac rugalmasságára. A munkanélküliség a tőkés termelés természetes velejárója, növekedése a globalizáció egyik jellemzője, szükséges velejárója, ugyanakkor a felgyorsult munkanélküli növekedés elsősorban a szakképzetlen munkások között jelenik meg. Gazdasági fellendülés idején a foglalkoztatás kisebb mértékben bővül, mint a kibocsátás, gazdasági visszaesés idején viszont gyorsabban csökken, mint a termelés. Rifkin szerint a munkaigény csökkenésének egyik fő oka a gépesítettség és automatizáltság fokozódása. [9]

\subsection{Rugalmasabb munkaerőpiac}

A globalizáció hatásaként megnőtt az igény a biztos foglalkoztatási formákra a bizonytalannal szemben, azt is mondhatnánk, hogy a tipikus foglalkoztatást felváltja az atipikus foglalkoztatás. Egyes országokban már az atipikus foglalkoztatás minősül tipikusnak. Növekszik a foglalkoztatásban eltöltött munkavállalók ledolgozott éve, a nyugdíjkorhatár is folyamatosan kitolódik. A munkába állás „adója” (bérterhek, szociális juttatások megvonása stb.) általában igen magas, ami megkérdőjelezi a 
munkavállalás ésszerűségét. Mindez azt jelenti, hogy mind a minimálbéren foglalkoztatottak, mind a különböző segélyekből élő munkanélküliek jövedelme elmarad a munkaerő újratermeléséhez szükséges minimális szinttől. [10]

\section{A kompetenciák szerepe a munkajogi szabályozásban}

A korábbiakban vázoltak szerint a digitalizáció jelentős hatással lesz a foglalkoztatásra és a munkavállalók helyzetére. Az előrejelzések alapján a munkavállalók jelentős részét fogja érinteni a digitalizáció. A digitalizációt jelen tanulmányunkban egységes jelenségként kezeljük majd. A digitalizáció része a robotizáció és automatizálás, a mesterséges intelligencia alkalmazása, illetve a gig economy keretében [11] történő munkavégzés. Mind sajátos kihívásokat fog a munkavállalók és a munkáltatók elé állítani. A digitalizáció folyamatát összefoglalóan nevezhetjük ipar 4.0 -nak [12], de vajon jog 4.0 is társul-e ezekhez a technológiai megoldásokhoz? Azt kell mondanunk, hogy nem. A jog követő rendszerként a fősodor kialakulása után kezdi el leszabályozni az új jelenségeket. Amíg ez nem történik meg, addig a meglévő jogi eszközök alkalmazásával szükséges megoldani a köztes időszakot. A köztes időszak kérdései megegyeznek a teljesen digitalizált korszak kérdéseivel. Hol helyezzük el a munkavállalót ebben a megváltozott keretrendszerben? Itt most az alkalmazott technológiától függetlenül szükséges erről beszélnünk, mivel a digitalizáció minden ágának egyik fő kérdése, hogyan adaptálható a munkavállaló, illetve, ha nem adaptálható, akkor milyen jogi eszközök alkalmazása segíti át a köztes időszakon?

Kezdetnek mindenképpen a munkajogviszony tartalmából szükséges kiindulnunk. Első lépésként a munkáltatónak a foglalkoztatáshoz való jogát kell megvizsgálnunk. Kell ezt annak a fényében tennünk, hogy az új digitalizált munkakörnyezet új kompetenciákat követel meg a munkavállalóktól. A digitalizáció és az internet terjedésével a kompetenciák alapvetően megváltoztak. A digitális kompetenciát az élethosszig tartó tanuláshoz nélkülözhetetlen nyolc kulcskompetencia egyike. Vannak olyan munkakörök, amelyek ezen digitális ismeretek nélkül is elláthatóak (az egyébként is alacsony végzettségű munkavállalók esete), de a dolgozók többsége magasabb digitális kompetenciával rendelkezik. Ezek elsajátítására több lehetőség áll rendelkezésükre, akár a formális oktatás keretében, akár a munka világában. A munkaadók számára viszont nagy kihívást jelent az egyes dolgozók közötti digitális szakadék megléte. Ehhez társul még, hogy a munkakörök napjainkban viszonylag gyorsan változnak: 5 évente a létező szakmák 5\%-a kicserélődik, az infokommunikációs technológiai (IKT) ismeretek nélkül űzhető szakmák száma 2 évente 5\%-kal csökken, az alapvető IKT ismeretek nélkül űzhető szakmák jövedelemtermelő képessége a minimálbér körül mozog, a megtanult szakmai ismeretek 10 év alatt elévülnek. Olyan kompetenciákra lesz szükség, melyek többségével a munkavállalók nem rendelkeznek jelen pillanatban. Az új kompetenciák megtanulása munkavállalói csoportonként eltérő időintervallumot fog jelenteni. Itt majd jelentősen el fognak egymástól válni a magasan képzett és az alacsonyan képzett munkavállalók lehetőségei. Mindezekhez kapcsolódó kérdés, hogy az új technológia alkalmazása mennyiben csökkenti az emberi munkavállalás lehetőségeit.

Kiindulópontunk, hogy a Munka törvénykönyvéről szóló 2012. évi I. tv. (továbbiakban: Mt.) 51.§. -ban fogalmazza meg azokat a kötelezettségeket, amelyeket a munkáltató köteles figyelembe venni és 
betartani a munkaviszony fennállásának teljes időtartamában. Az Mt. 51.§ (3) alapján a munkáltató a munkavállalót csak olyan munkára alkalmazhatja, amely testi alkatára, fejlettségére, egészségi állapotára tekintettel rá hátrányos következményekkel nem járhat. Ha egyszerűen szeretnénk megfogalmazni a megfelelő jogi keretek között olyan feladatokra lehet alkalmazni a munkavállalót, melyhez a testi és szellemi képességei megvannak, tehát rendelkezik a megfelelő kompetenciákkal. Ezért is kiemelten fontos, hogy a felek a munkaszerződésben meghatározzák a munkakört, mely azon feladatok, illetve munkák gyűjtőfogalma, amelyeket alkatának és képességeinek megfelelően el tud látni. [13] A kérdés ezek után az, hogy ha a munkavállaló már nem rendelkezik a megfelelő kompetenciákkal, akkor mi történik? Ha a munkavállaló nem rendelkezik a megfelelő kompetenciákkal és a munkáltató másképp nem tudja megoldani a foglalkoztatást, akkor a jogszabályban foglaltaknak megfelelően szükséges a jogviszonyt megszűntetni. Ez a megoldás kivitelezhető addig, amíg nem érinti tömegesen a munkavállalókat. Azonban, ha a digitalizációs és a megváltozott munkakörülmények új kompetenciákat követelnek meg az a munkavállalókat tömegesen fogja érinteni.

Ennek az érintettségnek két iránya lesz. Az egyik irány a gépek térnyerése a termelési folyamatok automatizálása során. A másik pedig a meglévő feladatkörök gyökeres átalakulása. Ezekhez kell hozzátennünk azt a tényt is, hogy a digitalizáció, mint új kihívás nem csak elveszi a munkahelyeket, de teremteni is fogja azokat. A kérdés azonban az, hogy a megszűnő és az új munkahelyek száma korrelále majd? Illetve melyek azok az új kompetenciák, amelyekre szükség lesz az új munkakörökben? Ezeket a kérdéseket még akkor is szükséges megvizsgálnunk, ha az Európai Unió Parlamentjének az Ajánlása egyértelműen megpróbál irányokat kijelölni a fenti kérdések kapcsán. Hajdú József tanulmányában kiemeli, hogy az Ajánlás szerint a robotika alkalmazásának fó iránya az emberi képességek növelése és nem a helyettesítése. Az Ajánlás fontosnak tartja kiemelni, hogy a robotika és a mesterséges intelligencia fejlesztése során mindvégig megmaradjon az emberi kontroll. [14] Azonban abban már nem vagyunk teljesen biztosak, hogy az EU által megfogalmazott irány ténylegesen is érvényesül majd. Félő, hogy gazdasági szempontok felülírják a fenti szempontokat és a vártnál is nagyobb mértékben fog leértékelődni a humán munkaerő. Annyi bizonyos, hogy az Európai Unió Bizottságának előrejelzése szerint a meglévő munkakörök közel 90\%-hoz szükséges valamilyen alapszintű digitális képesség megléte már most 2020-ban is.

Fontos, hogy a döntéshozók minél jobban megpróbálják rugalmasítani az oktatási rendszert, hogy a leendő munkavállalók már sokkal inkább képesek legyenek az új kompetenciák megtanulására. Ez sem azt jelenti majd, hogy nem kell újra tanulnia, hanem azt, hogy könnyebben fogja a még újabb kompetenciákat megtanulni. A nagyobb problémát nem is a most munkaerőpiacra belépő munkavállalók fogják jelenteni, hanem már a munkaerőpiacon lévő munkavállalók. A most munkaerőpiacra lépő generáció tagjai az ún. digitális bennszülöttek, akik készség szinten használják a digitális eszközöket. A kérdés azonban ugyanaz az összes most munkaerőpiacon lévő generáció vonatkozásában. Egy jelentős technológiaváltás következtében, hogyan és miképpen kezelhető az átképzés? Itt nem csak a költségekre gondolunk, hanem a tényleges megvalósításra. Az átképzés egy hatalmas teher lesz, melyet önmagában az államra testálni nem lehet, de a cégek sem feltétlenül biztos, hogy meg tudják egyedül valósítani. Fontosnak tartjuk, hogy az összes érintett bevonásával egy holisztikus szemléleten alapuló megoldást dolgozzanak ki a felek. Épen ezért a továbbiakban 
megpróbáljuk feltérképezni, hogy milyen eszközök állnak rendelkezésre a mai szabályozási struktúrában, melyek kiindulópontjai lehetnek.

Elfogadjuk Csordás és Füzesi megállapításait, miszerint azokban az országokban, ahol az alapvető digitális kompetenciával rendelkezők aránya magasabb, ott a harmonizált munkanélküliségi ráta alacsonyabb, mint azokban az országokban, az alacsonyabb digitális kompetenciával és alacsonyabb képzettséggel rendelkező munkavállalók esetében a munkanélküliségi ráta is magasabb. [15]

\subsection{Kompetenciák megszerzése munkaviszonyon belüli eszközök segítségével}

Részben a munkáltató felelőssége is, hogy a munkavállaló képes legyen a minél gyorsabb adaptálódásra. Ezért a legegyszerűbben alkalmazható jogi eszköz, ha a munkáltató utasításba adja valamilyen olyan képzés elvégzését, mely képes fejleszteni a munkavállaló képességét és tudását. $\mathrm{A}$ munkáltató elég széles körben rendelkezhet az utasításadási jogával a megfelelő jogi keretek között. Amíg az utasítás a jogi keretek között marad, addig az utasítás végrehajtása kötelező. Azt is figyelembe kell venni, hogy az utasításba adott iskoláztatás nem feltétlenül bír motiváló erővel, másrészt teljes biztosítékot sem ad arra, hogy a munkavállaló a tudását a munkáltatónál fogja kamatoztatni. Sokkal hatékonyabban alkalmazható lehet a tanulmányi szerződés alkalmazása. A tanulmányi szerződés célja, hogy a munkáltató a felmerülő szakember szükségletét biztosítsa. [16] A tanulmányi szerződés alkalmazása egyrészt növelheti a munkáltatók versenyképességét, illetve lehetőséget teremthet számukra, abban, hogy magasan képzett munkaerő legyen a birtokukban. A tanulmányi szerződés egy befektetés is munkáltatói oldalról, amely biztosítja, hogy a piaci igények által megkívánt tanulmányok elvégzését követően szakmailag képzett munkavállalókkal rendelkezzenek, akik a piaci kihívásoknak megfelelő, a munkáltató elvárásaihoz igazodó munkát végezzenek. [17] A munkaerőpiac szereplőinek, de elsődlegesen a munkavállalóknak arra kell ráébredniük, hogy az egyetlen esély a tartósan munkaerőpiacon maradáshoz az élethosszig tartó tanulás. A tanulmányi szerződés kiváló keretet biztosít ennek megvalósításához. Ezeket a kereteket biztosítja, hogy a tanulmányi szerződés a munkaviszonyhoz kapcsolódó polgári jogi alapú szerződés, melyben a felek egyenlők. A tanulmányi szerződés a közös kapcsolódási pontokra épül. A munkavállaló a szükséges képzés elvégzését követően vállalja, hogy meghatározott ideig a munkáltatónál végzi a munkáját. A munkavállaló a tanulmányi szerződésben meghatározott ideig, de legfeljebb a képzettség megszerzését követő maximum öt évig felmondással nem szüntetheti meg a jogviszonyát. A tanulmányi szerződés és a munkaszerződés annyiban szétválik, hogy a munkaviszony felmondása jogszerű lesz, de ez eredményezi majd a tanulmányi szerződés megszegését, aminek jogi következményei vannak. Az azonban érzékelhető, hogy a tanulmányi szerződések tömeges alkalmazása jelentős adminisztrációs és munkaszervezési terhet is róhat a munkáltatóra, így elsősorban az átmeneti időszakban alkalmazott jogi eszközként tekinthetünk rá. Illetve azon munkáltatók esetében, ahol az optimális üzemméret ezt lehetővé teszi. A tanulmányi szerződés létjogosultsága nem csak az átmeneti időszakban lesz fontos, hanem a fent említett korlátok között a későbbiekben is. Az alkalmazhatóságát jelentősen fogja befolyásolni, hogy a technológiaváltások milyen gyorsan követik majd egymást. Természetesen önmagában a tanulmányi szerződés nem lesz elegendő. Szükség lesz ehhez munkajogon kívüli eszközök alkalmazása is. 
Mielőtt azonban neki kezdünk a munkajogon kívüli eszközök elemzésének meg kell említenünk egy olyan megoldást, mely a munkajogi szabályozás egyik hiátusa. Ez a hiátus a 2012-ben hatályba lépett Mt.-vel keletkezett, amikor a jogalkotó nem látta indokoltnak a továbbtanuló munkavállalók védelmének a fenntartását. Természetesen annak ma sincs akadálya, hogy valaki a munkája mellett olyan tanulmányokat folytasson, amely nem szolgálja a munkáltatója érdekét. A korábbi jogszabályok azonban a vizsgák idejére, illetve a szakdolgozat elkészítésének idejére pótszabadságok adását tette kötelezővé. Ha nem is direkt módon, de ez a lehetőség is segítette, hogy a munkavállalók olyan kompetenciákhoz jussanak, amelyeket akár a saját már meglévő, vagy későbbi munkájuk során is használni tudnak. A jogalkotónak esetlegesen érdemes lehetne elgondolkodni a szabályozás visszaállításán.

A lehetőségek mellett azonban a gátló tényezőket is fel kell sorolnunk. A gátló tényezők egy része összekapcsolódik a munkaerőhiánnyal. A munkáltatók egy része azért nem hajlandó képzésbe invesztálni, mert attól fél, hogy a munkavállalói elmennek tőle, mihelyst megtanulták, amit kell. Ezen felül a továbbtanuló munkavállalók is sokszor félnek bevallani, a munkahelyükön, hogy tanulnak, mert attól félnek rossz szemmel nézne rájuk a főnökség. Ezek a gátló tényezők pedig képesek olyan patthelyzetek kialakítására, mely közép és hosszú távon sem munkavállalónak, sem a munkáltatónak nem lesz jó.

\subsection{Munkaviszonyon kívüli eszközök}

Az új kihívásokkal történő szembenézés nem lehetséges csak a munkajog eszközeivel. Érdemes megvizsgálnunk azokat a foglalkoztatáspolitikai eszközöket is, melyekre akkor van szükség, ha már a munkajogi szabályokat nem tudjuk alkalmazni. Ez akkor fordulhat elő, ha a munkavállaló az új digitalizált környezetben elveszíti a munkáját, vagy rövid időn belül el fogja veszíteni. A munkavesztés egyik oka lehet majd, hogy az automatizált munkavégzési folyamatok bevezetése, amelynek következtében vagy ismeretei hiányában nem tudja a munkáját elvégezni. A kérdés azonban, hogy azok a munkavállalók, akik a digitalizáció következtében veszítik el a munkájukat, hogy és miként szerezhetik meg az új kompetenciákat? A kérdésre a választ a Foglalkoztatás elősegítéséről és a munkanélküliek ellátásáról szóló 1991. évi IV. tv elemzésével kereshetünk (továbbiakban Flt.). Az elemzés keretében két jogintézményt szükséges megemlítenünk. Az egyik az aktív foglalkoztatáspolitikai eszközök között megtalálható „Képzések elősegítése” a másik pedig a passzív foglalkoztatáspolitikai eszközök között lévő „Álláskeresési járadék”.

\subsubsection{Képzések elősegítése}

Mindenképpen fontos kiemelni, hogy az új kompetenciák megszerzése nem csak az egyén felelőssége, hanem társadalmi érdek is, hiszen a munkavállalókra szükség lesz az új munkakörökben is. Az új képességek és kompetenciák megszerzésére pedig a képzéséken való részvétel nyújt lehetőséget. Éppen ezért, fontos kiemelni az Flt. 14.§-át mely szerint támogatható az állami foglalkoztatási szerv által felajánlott, vagy elfogadott képzése annak a személynek:

a) aki álláskereső, 
b) pályakezdő álláskereső

c) aki gyermekgondozási segélyben, gyermekgondozást segítő ellátásban, gyermeknevelési támogatásban, gyermekgondozási díjban, gyermekek otthongondozási díjában vagy ápolási díjban részesül,

d) aki rehabilitációs ellátásban részesül,

e) akinek munkaviszonya várhatóan egy éven belül megszűnik, és ezt a munkaadó a munkavállalóval és az állami foglalkoztatási szervvel előzetesen írásban közölte, vagy

f) aki közfoglalkoztatásban vesz részt, és a képzésben való részvételt vállalja, továbbá

g) aki munkaviszonyban áll és rendszeres foglalkoztatása képzés nélkül nem biztosítható.

A jogszabályban meghatározott személyi kör elég széles. A tanulmány keretei között mindegyik személyi csoportra nem tudunk kitérni. Azt azonban mindenképpen szükséges elmondanunk, hogy a felsorolt személy csoportok a későbbiekben is a kiszolgáltatottabb személyi körökhöz fognak tartozni. A jelen tanulmány szempontjából három személyi csoportot szükséges kiemelnünk:

- az álláskeresőt

- pályakezdő álláskereső

- aki munkaviszonyban áll és rendszeres foglalkoztatása képzés nélkül nem biztosíthat

Az álláskereső az a személy az Flt 58.§ (5) d. pontja alapján, aki

- a munkaviszony létesítéséhez szükséges feltételekkel rendelkezik, és

- oktatási intézmény nappali tagozatán nem folytat tanulmányokat, és

- öregségi nyugdíjra nem jogosult, rehabilitációs járadékban, valamint a megváltozott munkaképességű személyek ellátásaiban nem részesül és

- az alkalmi foglalkoztatásnak minősülő munkaviszony és a nevelőszülői foglalkoztatási jogviszony kivételével munkaviszonyban nem áll, és egyéb keresőtevékenységet sem folytat, és

- elhelyezkedése érdekében az állami foglalkoztatási szervvel együttmüködik, és akit

- az állami foglalkoztatási szerv álláskeresőként nyilvántart.

Ehhez képest a pályakezdő álláskereső az a személy, aki a 25. életévét — felsőfokú végzettségú személy esetén 30 . életévét - be nem töltött, a munkaviszony létesítéséhez szükséges feltételekkel rendelkező, az állami foglalkoztatási szerv által nyilvántartott álláskereső, feltéve, ha munkanélküli járadékra a tanulmányainak befejezését követően nem szerzett jogosultságot.

Fontos kiemelni, hogy ez a két réteg lehet a megfelelő képzési struktúra kialakításával akár egy fontos bázisa a jövő humánerőforrás szükségletének. Ehhez azonban megfelelő képzések kellenek. Jelen helyzetben azonban még nem igazán tudjuk pontosan, hogy milyen változásokat hoz a munka világában a digitalizáció és milyen új kompetenciákra lesz szükség. De amint ez ismerté válik a lehető legrövidebb időn belül szükséges lesz az álláskeresők megfelelő képzésére. De persze nem ennyire idillikus a kép. Egyrészt a képzések támogatása az egyik legköltségesebb aktív foglalkoztatáspolitikai eszköz. A képzési programok célja a célcsoport ellátása olyan tudással (humán tőkével), melyet a célcsoport foglalkoztathatóságát hosszú távon növelheti meg. [18] Másrészt kérdéses, hogy a 
képzésekben résztvevők mekkora százalékán és milyen időintervallumon belül lehet eredményt elérni. Fontos kiemelni, hogy ebben a pontban kettéválik az alacsony végzettségú és magasan kvalifikált személyek csoportja. Nem arról van szó, hogy melyikük jobb, hanem ahogy azt Kopp és társai is kiemelik más kompetencia készlettel rendelkeznek, ezért az alacsonyabb képzettségű személyeknek hosszabb idôbe telhet ugyanazon kompetenciák megszerzése. [19] A magasan kvalifikált munkaerőnek ez sokkal rövidebb időt vesz igénybe, ha egyáltalán kerül olyan helyzetbe, hogy munkaviszonyon kívül kelljen megszereznie a tudást. Sokban hasonlít azon munkavállalók helyzete, akiknek a munkaviszony fenntartáshoz szükséges ilyen képzésen részt vennie. Hasonló, de nem azonos, ugyanis a többiekkel ellentétben neki nem szűnt meg a jogviszonya, sőt ha sikeresen részt vesz a képzésen valószínúleg nem is fog. A másik két csoport esetében a képzés nem a bent maradáshoz, hanem az újra bekerüléshez kell. A képzés időtartamára juttatás jár. Azok esetében, akik munka mellett végzik kereset-kiegészítés formájában kapják, akik álláskeresőként azok pedig keresetpótló juttatásként. Ennek célja, hogy a képzés időtartama alatt is biztosított legyen az illető megélhetése egy bizonyos szintig. A kereset-kiegészítés a képzést megelőzően elért havi átlagjövedelem és a képzés alatt elért kereset különbözetéig terjedhet. A keresetpótló juttatás összege nem lehet alacsonyabb a megállapításakor hatályos kötelező legkisebb munkabér 60 százalékánál, és nem haladhatja meg a megállapításakor hatályos kötelező legkisebb munkabér összegét. Az összegek nem túl magasak, ami nem feltétlenül motiváló, de talán az Flt.-ben található lehetőségek közül az egyik legalkalmasabb. A kérdés azonban, hogy ha a megváltozott munkakörülmények között megnövekszik az igénybevétel, akkor mennyire lesz finanszírozható a Nemzeti Foglalkoztatási Alapból, ha ezeket a nyomott támogatási mértékkel is az egyik legköltségesebb eszköznek tartjuk? Kifejezetten fontos kérdés lesz annak fényében, hogy a digitalizáció valószínűleg magával fogja hozni az élőmunkára eső adóterhek csökkenését, így a befizetett összegek csökkenését is, hacsak nem kerülnek megadóztatásra azok a javak, melyek a gépi munkaerő használatából fakad. A kérdés, mint mindig az ellátás fenntarthatóságának a kérdése. [14]

A fentiekből is látszik, hogy a foglalkoztatás mikéntje egy komplex rendszer egyik elemeként lesz értelmezhető, mely összekapcsolódik a financiális kérdésekkel. Ezek a kérdések kiterjednek majd azon előbb említett munkavállalókra is, akiknek a képzésére azért van szükség, hogy tovább lehessen foglalkoztatni. Ez kiegészül azzal a lehetőséggel, hogy a munkáltató maga kér képzéseket, melyek feltételeit leegyezteti a Kormányhivatallal. Ez a magatartás a meglévő gazdasági érdeken túl beleillik az adott munkáltató társadalmi felelősségvállalási politikájába (továbbiakban: CSR) is akár, mely az állami oldalról ki kell, hogy egészüljön a társadalmi közfelelősség vállalással (továbbiakban: PSR). Jakab és Ráczi kiemelik, hogy a társadalmi értéktörvény alkalmazásának számos pozitív kimenetele lehet. A lehetséges eredményeket három kategóriába oszthatjuk be: melyből az egyik a foglalkoztatás és gazdasági növekedés körébe tartozik, a másik az egészség, jólét és környezet tárgykörébe, és végül a harmadik közösségre gyakorolt hatások csoportjába. [20] A jogi eszközök mellett olyan jogon kívüli eszközök alkalmazása is szükséges lesz a jövő munkaerőpiacán, mint a CSR és PSR esetleges összekapcsolása, hiszen mind az állam, mind a vállalkozások felelőssége, hogy segítse a kiszolgáltatottabb felet, aki a munkavállaló és az álláskereső. A fentiekből is kitűnik, hogy a képzés sem önmagában fogja megoldani a problémát, és külön a munkajogi eszközök sem. Ez különösen igaz, hogy eddig csak azokról az esetekről beszéltünk, amikor sikerül a munkavállalót és/vagy az álláskeresőt 
képezni. Az eddig feldolgozott jogintézmények azt próbálják meg garantálni, hogy sikeres képzés után lehetőség nyílik a további foglalkoztatásra. Ezt próbálja meg biztosítani a tanulmányi szerződés és a képzések elősegítése is.

Arról is beszélnünk szükséges, hogy a maradék elv alapján lesznek olyan csoportok, akik nem lesznek képesek az adaptálódásra és nem tudják megszerezni az új kompetenciákat.

\subsection{2.Álláskeresési járadék}

A tanulmányunkban a munkaerőpiac jogi és gazdasági kihívásaival foglalkozunk, éppen ezért foglalkoznunk szükséges olyan lehetőségekkel is, melyek szerint a munkavállalók, illetve az aktív korú népesség egy része nem lesz képes megtanulni azokat az új kompetenciákat, melyek ahhoz lesznek szükségesek, hogy az új körülmények között munkavállaló lehessen. A kérdés, hogy a ma meglévő jogi keretrendszerünk elegendő védelmet nyújt-e ebben az esetben? Azt kell, hogy mondjuk, hogy az álláskeresési járadék a mostani formájában sem képes betölteni a funkcióját. A folyósításának időtartama maximum 90 nap. Ennél csak kevesebb lehet. Tíz nap jogosultsági idő egy nap járadékfolyósítási időnek felel meg. Ez az időszak egészülhet ki a felmondási idővel, abban az esetben, ha a munkajogviszony munkáltatói felmondással szűnt meg. Azonban az érzékelhető, hogy önmagában az álláskeresési járadék nem lehet megoldás azok számára, akik a megváltozott munkakörülményekhez nem képesek alkalmazkodni. A maximum 90 napos ellátás rövid időtartamú. Az álláskeresési járadék lejártát követően aktív korúak ellátására való jogosultság állapítható meg, mely a minimál nyugdíj összegéhez (28 500 Ft) kötött ellátás. Ebből következően, akinek nem lesz meg a nyugdíj jogosultsága, de nem tudja az új ismereteket megszerezni azok számára az említett konstrukció ebben a formában nem fog segítséget nyújtani. A döntéshozóknak a fentiek fényében teljes mértékben át kellene értékelnie a későbbiekre, hogy milyen támogatási rendszereket alakítanak ki, mindezt annak a függvényében, hogy ezek a jogintézmények már a mai viszonyaink között sem teljesítik be funkciójukat. [21] Érdemes lenne új alapokra helyezni majd az ellátásokat. Ehhez azonban mindenképpen a komplex látásmód szükséges, mely két alapra épít az élethosszig tartó tanulás támogatására és a társadalmi felelősségvállalásra.

\section{A társadalmi felelősségvállalás és az élethosszig tartó tanulás kapcsolata}

Ahogy a korábbiakban is említettük az új munkaerő-piaci kihívások a digitalizációhoz kapcsolódva olyan jogi eszközök kialakítására lesz szükség, mely támogatja az élethosszig tartó tanulás lehetőségét. Elsősorban a ma létező jogintézmények fejlesztésére lesz szükség, illetve az adott kor igényeinek megfelelő kiegészítésére. Ennek a kialakításában segíthet, ha a vállalatok (a kis- és középvállalatok is) tömegesen és hatékonyan alkalmazzák a CSR-t és az állam / önkormányzat is figyelemmel lesz a PSR alkalmazására. A CSR esetében is egyre inkább elfogadott tény, hogy annak nem csak a vállalaton kívül kell megvalósulnia, hanem szükséges egy fajta belső CSR alkalmazása a munkavállalók irányába is. Az általunk felvázolt jövőbeli kihívások a kettő megfelelő kombinációját feltételezik kiegészülve az állami plusz felelősségvállalással. Hiszen mindezeknek az általunk felrajzolt változásoknak társadalmi hatásai is lesznek, ezért a kialakítandó jogi megoldásoknak egyszerre kell majd fókuszálni a közösségre és az 
egyénre is. A megoldás magva az aktív eszközökben kell, hogy gyökerezzen majd, ami a képzés területe, de nem szabad elfelejteni, hogy ennek kizárólagossága nem oldaná meg a teljes problémát. A rendszerek kialakításánál figyelembe kell venni az emberi tényezőt. Az emberi tényező, mindig az ember saját korlátaival van összefüggésben, illetve azzal, hogyan tudja önmaga megteremteni a saját maga és családja számára a szociális biztonság feltételeit. A jövő munkaerő-piaci és munkajogi eszközeinek arra kell törekednie, hogy általuk a munkavállaló képes legyen biztosítani saját maga és családja megélhetését. Vonatkozik ez azokra az esetekre is, ha történetesen nem tud alkalmazkodni a megváltozott körülményekhez. A jogalkotó legfőbb dilemmája az lesz, hogy meddig terjedhet ez a fajta gondoskodás. Ebben a relációban a skála egyik végén a minimális szintű gondoskodás áll, a skála másik végén az alanyi jogon járó ellátások kibővítése. A legtöbb kérdést ez utóbbi hordozza, ezért röviden szeretnénk bemutatni jogi és gazdasági szempontból is.

\subsection{Az alapjövedelem kérdése}

Vobruba A teljes foglalkoztatás alternatívái című könyvében részletesen ír a bérmunka társadalmának válságáról és arról, hogy a korábban elvárt teljes foglalkoztatásról végleg le kell mondani. Három szakaszra osztja a bérmunka fejlődését: (1) az iparosodástól a 20. század közepéig tartó korszak, ahol a természetbeli jövedelmek helyett pénzjövedelmek kerültek előtérbe, (2) a 2. világháborútól a 21. századig terjedő időszakban a juttatások a bérmunkához és a fizetésekhez kapcsolódtak (ekkor lehetett teljes foglalkoztatásról beszélni), (3) a jövőben a társadalom tagjai inkább több, egymást kiegészítő jövedelemforrásból fedezik az igényeiket. Vobruba alternatívát adott a bérmunka krízisére, a kilencvenes években a keresőtevékenységgel kombinált alapjövedelem gondolata került előtérbe, amely az ún. kettős gazdaságot jelenti. A kettős gazdaság képviselői szerint a gyenge teljesítőképességűek vagy munka nélkül maradtak újra integrálódhatnak a munkaerőpiacra és ettől remélik, hogy a szegénység szegregációs hatása visszaszorul. [22] Vobruba munkásságában „kibontakozó új típusú vegyes jövedelmű gazdaságban a saját munka kap mind nagyobb helyet a jövedelemszerkezetben, miközben a szociális ellátórendszernek az alapjövedelem garantálásában játszott szerepe fokozatosan visszaszorul." [23]

A jövő gazdaságának kialakításáról alkotott képnek viszont igenis része az alapjövedelem. Az egyik legélénkebb vita középpontjában áll, mely a digitalizáció és robotizáció által életre keltett kihívások egyik lehetséges eszköze. [24] [25] A konstrukció lehetőségével az Európai Parlament által az Európai Bizottságnak szóló a robotikára vonatkozó polgári jogi szabályokról szóló ajánlásának 44. pontjában foglalkozik. Az Európai Parlament kéri a Bizottságot, hogy elemezze a különféle lehetséges forgatókönyveket, valamint azok következményeit a tagállamok szociális biztonsági rendszereinek életképességére nézve. A dokumentum azt a nézetet vallja, hogy inkluzív vitát kell kezdeni az új foglalkoztatási modellekről, valamint adó- és társadalombiztosítási rendszereinknek a megfelelő jövedelemszint melletti fenntarthatóságáról, ideértve egy általános alapfizetés ${ }^{1}$ esetleges bevezetését is. A közelmúltban számos kísérlet történt, így például Finnországban is, de korábban több holland

\footnotetext{
1 A dokumentum magyar fordításában az alapfizetés kifejezés szerepel eredetileg, ami kissé félrevezető lehet. Az eredeti angol szövegben basic income megjelölésben található fogalom. A basic income szokásos fordítása alapjövedelem vagy feltétel nélküli alapjövedelem.
} 
város is kísérletezett vele. [24] A kísérletek eredményei felemásak lettek, se nem kifejezetten pozitív, de nem is rossz.

$\mathrm{Az}$ alapjövedelem esetében a fő kérdés az, hogy feltételnélküli legyen-e, vagy feltételekhez kötött. A legelfogultabb hívei, köztük Parijs is azt hangsúlyozza, hogy az alapjövedelemnek feltétel nélkülinek kell lennie, mert csak ez biztosítja azt a lehetőséget, mely biztosítja az egyén szabadságát és csökkenti a kiszolgáltatottságát a munkaerőpiacon. [26] Az alapjövedelem alanyi jogon járó ellátásként fogalmazódik meg, mely állampolgári alapon járna. Ha ezt átültetjük az eddigi elemzésünkbe, akkor azon köztes élethelyzetek áthidalása kapcsán merül fel a konstrukció, mely a digitalizáció miatt a munkájukat vesztett személyeken való segítést jelentené. Felmerülhet a kérdés azonban, ha minden munkavállaló potenciális veszélyeztetett amiatt, hogy elveszítheti állását, akkor miért ne lehetne mindenkire kiterjeszteni a feltételnélküli alapjövedelmet? A kérdés annyiban talán jogos lehet, hogy nem fog mindenki beleférni a képzési programokba elsőre. Illetve lesznek, akiknek hosszabb idő kellhet a munkaerőpiacra való áttéréshez. Itt tipikusan ismételten a magasan és alacsonyan kvalifikált munkaerő kettőségéről kell beszélnünk. Tipikusan azoknak kellhet több idő, akik még az alapkompetenciákkal sem rendelkeznek. Az ő szempontjukból kiemelten fontos lehet a megélhetésük biztosítása okán. A konstrukciót mindenképpen szükséges átgondolni, ugyanis hiába emeljük ki, hogy a CSR a PSR és az LLL hármasa lesz a meghatározó, amit szükséges új alanyi jogon járó ellátásokkal kiegészíteni, ha a magánszektor és főleg az állami teherbíróképesség nem lesz képes ennek a megvalósítására. ${ }^{2} \mathrm{Az}$ alapjövedelem pártolói a fogyasztási típusú adókból látják finanszírozhatónak a rendszert. Ami több és további kérdést is felvet. Ha a digitális technológia miatt tömegesen veszítik el az emberek a munkájukat, akkor valószínúleg a fogyasztás is csökkeni fog. Hirtelen apadó adóbevételből kellene megvalósítani a teljes rendszer finanszírozását. Artner szerint egyszerűsítve ez azt jelenti, hogy a megtermelt érték realizálása tehát így is, úgy is a tőketulajdonosokon múlik: vagy munkások foglalkoztatására fordítják, munkabért fizetve nekik, vagy maguk költik el fogyasztási cikkekre (luxusjavakra) és beruházási eszközökre, vagy az adófizetés révén az államon keresztül ugyanezekre. [25]

Annyi bizonyosan elmondható, hogy a feltétel nélküli alapjövedelem egymagában önálló szociális rendszerként nem fog megvalósulni. Azt azonban hozzá kell tenni, hogy a benne rejlő szociális gondolatot mindenképpen fontos kiemelni. A jövő ellátórendszerében egy megfelelően balanszírozott rendszerben az ellátások arányát szükséges lehet áttolni az ideiglenes, átmeneti időszakokra alkalmazott alanyi jogú ellátások irányába. Nem feltétlenül kell, hogy az ellátórendszer fő karakterét adják, de a jövő munkavállalóinak és álláskeresőinek szüksége lesz ezekre a megoldásokra, hogy megtalálják a helyüket az új munkaerő-piaci struktúrában.

\section{4. Összefoglalás}

A munkaerőpiac átalakulása minden munkakört fog érinteni valamilyen szinten a közeljövőben, sőt egyes munkakörök már át is esetek ezen az átalakuláson. [27] Lesz olyan, amelyiket jobban, és lesz

\footnotetext{
2 Történtek már komplett számítások a teljes magyar költségvetés vonatkozásában is, in:
} http://let.azurewebsites.net/upload/tanulmany.pdf , (2018.12.31.) 
olyan is, amelyiket kevésbé. A mai ismereteink szerint már előrejelzésekkel is tudunk szolgálni azzal kapcsolatban, hogy középtávon mely foglalkozásokat fogja a leginkább érinteni a digitalizáció. Vannak egyszerűbben kezelhető applikációk, mint például a BBC alkalmazása, mely a foglalkozás nevének a beírásával megadja, hogy a közel jövőben mekkora valószínűséggel fogja robot átvenni a humán munkaerő helyét. [28] Persze vannak komplettebb, inkább szakmai elemzések is, mint a tanulmányunkban hivatkozott írások. Mindenesetre olyan komplex megoldásokra lesz szükség, melyek egyszerre kezelik a problémák jogi-gazdasági- és társadalmi oldalát. A foglalkoztatás nem csupán jogi, gazdasági vagy társadalmi kérdés, hanem ezek elegye, éppen ezért a megoldásoknak tükrözniük kell majd a holisztikus megközelítést. Az egyelőre távolinak tűnő kérdések pár éven belül itt lesznek és a megfelelő válaszokat kell rá megtalálni, amely azért is lesz nehéz, mert eltérő sebességgel reagál a jog, a gazdaság és a társadalom is ugyanarra a jelenségre általában. Nem lesz ez másképp a munkaerőpiac digitalizációja kapcsán sem. Éppen ezért lenne szükséges mindazokat az elemeket és problémahalmazokat a döntéshozónak egy csomagként kezelnie, amiket a korábbiakban vizsgáltunk és elemeztünk.

Tanulmányunkban az általános problémahalmazt szerettük volna feltárni, s mindezt vitaindító jelleggel. A döntéshozók a konkrét megoldásokról és eszközökről a probléma kikristályosodásakor tud dönteni, de ez nem jelenti azt, hogy preventív eszközökkel már most ne tompíthatná ezek későbbi negatív hatásait. A legfontosabb preventív eszköz pedig az oktatás megfelelő szinten tartása és rugalmasítása és annak szorgalmazása, hogy az aktív korú népesség lehető legnagyobb része rendelkezzen olyan alapkompetenciákkal, melyre a későbbiekben az új környezethez szükséges tudást alapozni lehet. A döntéshozó ezt kezelhetné egyfajta társadalmi befektetésnek, annak elfogadása mellett, hogy hasznot nem azonnal fog hozni, hanem idővel beérik. Pont akkorra, amikor a legnagyobb szükség lesz rá.

\section{Hivatkozások}

[1] J. Gács (2007) A gazdasági globalizáció számokban, - A nyitottság alakulása az EU országaiban I. rész. Közgazdasági Szemle 54(10) pp. 876-902.

[2] H-P. Martin, H. Schumann (1998) A globalizáció csapdája: Támadás a demokrácia és a jólét ellen. Perfekt Kiadó: Budapest

[3] R. Castel (1996) Work and usefulness to the world. International Labour Review 135(6) pp. 615-622.

[4] M. Almási (1998) Üveggolyók - az ezredvég globális játszmái? Helikon Kiadó: Budapest

[5] D. Rodrik (2011) A kereskedelem hatása a munkapiacokra és a munkavállalói viszonyokra. pp. 325-330. In: Scheiring - Boda: Globalizáció és fejlődés (szöveggyűjtemény)

[6] G. Nagy Gábor (2010) A világgazdaság és a globális munkaerőpiac. In: Mészáros: A globális gazdaság földrajzi dimenziói, Akadémiai Kiadó: Budapest, pp. 229-248. 
[7] Zs. Dabasi-Halász, K. Lipták, J. Kiss, I. Manafi, D.E. Marinescu, M. Roman, J. LorenzoRodriguez (2019) International youth mobility in Eastern and Western Europe - the case of the Erasmus+ programme. Migartion Letters 16(1) pp.61-72.

[8] J. van den Broeck (1996) The economics of labour migration. Elgar Kiadó, Cheltenham Brookfield

[9] J. Rifkin (1995) The end of work - The Decline of the Global Labor Force and the Dawn of the Post-Market Era. Tarcher/Putnam: New York

[10] A. Artner (2006) A globalizáció alulnézetben: Elnyomott csoportok - lázadó mozgalmak. Napvilág Kiadó: Budapest

[11] H. Tóth (2018) A változó munkajogi környezet hatása az innovációra. Miskolci Jogi Szemle 2018/2.pp. 65-77.

[12] J. Oláh (2019) Az Ipar 4.0 keretrendszere, valamint a kapcsolódó technológiák. International Journal of Engineering and Management Sciences 4(4) pp. 213-223. DOI: 10.21791IJEMS.2019.4.24

[13] Z. Bankó, Gy. Berke, Gy. Kiss. (2017) Kommentár a Munka törvénykönyvéhez. Wolters Kluwer: Budapest

[14] J. Hajdú (2017) A munkavégzés jövője: A robotika forradalmának jövője a munkaerőpiacra. In: Gellén K. [ed.] Jog, innováció, versenyképesség. Wolters Kluwer: Budapest pp.31-58.

[15] A. Csordás, I. Füzesi (2019) Digitális kompetenciaszintek valamint a munkanélküliség és a vállalati továbbképzések közötti kapcsolatok az Európai Unióban. International Journal of Engineering and Management Sciences 4(3) pp. 197-209. DOI: 10.21791/IJEMS.2019.3.19.

[16] I. Rácz (2017) Tanulmányi szerződés. In: Kun A. [ed.]. Az egész életen át tartó tanulás (lifelong learning) jogi keretei a munka világában, különös tekintettel a munkaviszonyra. Patrocínium Kiadó: Budapest. pp.110-144.

[17] B. E. Pándiné (2015) A tanulmányi szerződés munkaerő-piaci és jogi megközelítésből. Economica 8(1) pp. 29-34.

[18] N. Bíró, Gy. Nádas, T. Prugberger T, H. Rab, P. Sipka (2010) Az aktív és passzív foglalkoztatáspolitikai eszközök. Foglalkoztatási és Szociális Hivatal. Budapest

[19] R. Kopp et al. (2019) Sociotechnical perspectives on digitalisation and Industry 4.0. Sociotechnical perspectives on digital. International Journal of Technology Transfer and Commercialisation 16(3) pp. 290-309. DOI: 10.1504/IJTTC.2019.099896

[20] N. Jakab, Z. Ráczi (2019) A társadalmi közfelelősség kérdései Nagy-Britanniában és Magyarországon. Pro Futuro 9(1) https://doi.org/10.26521/Profuturo/1/2019/3908

[21] Zs. Ferge (2017) Magyar társadalom- és szociálpolitika - 1990-2015. Osiris Kiadó: Budapest

[22] G. Vobruba (2005) Alternativen zur Vollbeschäftigung: Die Transformation von Arbeit und Einkommen, Suhrkamp: Frankfurt am Main 
[23] J. Csoba (2010) A tisztes munka: A teljes foglalkoztatás: a 21. század esélye vagy utópiája? Kísérletek a munka társadalmának fenntartására s a jóléti állam alapvető feltételeként definiált teljes foglalkoztatás biztosítására, L’Harmattan Kiadó: Budapest

[24] S. Paba, G. Solinas (2018) In Favour of Machines (But Not Forgetting the Workers): Some Considerations on the Fourth Industrial Revolution. In: Ales, E. - Curzi, Y. Fabbri, T. Rymkevich, O. - Senatori, I. - Solinas, G. [eds.] Working in Digital and Smart Organizations. Palgrave McMillan (e-book) pp. 39-64.

[25] A. Artner (2019) A technológiai változások és a munka. Munkaügyi Szemle, 2019/4. pp. 613.

[26] P. V. Parijs (2010) Alapjövedelem: egy egyszerű és erőteljes gondolat a huszonegyedik század számára. Esély, 2010/5. pp. 9-41.

[27] Z. Rácz (2019) Az ügyvédi hivatás jövője a robotika fejlődésének fényében. Advocat 2019/1. pp. $9-12$.

[28] Will a robot take your job? https://www.bbc.com/news/technology-34066941 (2019. 12.30.) 